\title{
Synthesis and Characterization of Branched Sulfonated Poly(ether sulfone ketone) as Proton Exchange Membrane
}

\author{
By Dong Wan SEO, ${ }^{1}$ Hye Seok PARK, ${ }^{1}$ Seung Woo CHOI, ${ }^{1}$ \\ Young Gi JEONG, ${ }^{1}$ Tae Whan HoNG, ${ }^{2}$ and Whan-Gi KIM ${ }^{1, *}$
}

\begin{abstract}
Branched sulfonated poly(ether sulfone ketone)s (Br-SPESK) were prepared with bisphenol A, 4,4'-difluorobenzophenone, 3,3'-disodiumsulfonyl-4,4'-difluorophenylsulfone, and THPE (1,1,1-tris-p-hydroxyphenylethane), respectively, at $160^{\circ} \mathrm{C}$ using potassium carbonate in DMAC (Dimethylacetamide). THPE, as a branching agent, was used with $0.4 \mathrm{~mol} \%$ of bisphenol A to synthesize branched copolymers. Copolymers containing $10-50 \mathrm{~mol} \%$ disulfonated units were cast from dimethylsulfoxide solutions to form films. Linear sulfonated poly(ether sulfone ketone)s (SPESK) were also synthesized without THPE. The films were converted from the salt to acid forms with dilute hydrochloric acid. A series of copolymers were studied by FT-IR, ${ }^{1} \mathrm{H}$ NMR spectroscopy, differential scanning calorimetry (DSC), and thermogravimetric analysis (TGA). Sorption experiments were conducted to observe the interaction of sulfonated polymers with water and methanol. The ion exchange capacity (IEC), a measure of proton conductivity, was evaluated. The synthesized Br-SPESK and SPESK membranes exhibit conductivities $\left(25^{\circ} \mathrm{C}\right)$ from $1.02 \times 10^{-3}$ to $4.53 \times 10^{-3} \mathrm{~S} / \mathrm{cm}$, water swell from 22.25 to $61.50 \%$, IEC from 0.35 to $0.81 \mathrm{meq} / \mathrm{g}$ and methanol diffusion coefficients from $3.10 \times 10^{-7}$ to $4.90 \times 10^{-7} \mathrm{~cm}^{2} / \mathrm{S}$ at $25^{\circ} \mathrm{C}$.

KEY WORDS: Branched Polymer / Fuel Cell Membrane / Branching Agent / Poly(ether sulfones) / Poly(ether ketones) /
\end{abstract}

Because of increasing demand for fuel cells in transportation and portable electronics, proton-exchange polymer membranes for fuel cells have recently received much attention. The stateof-the-art proton exchange membranes, which include perfluorinated polymers containing sulfonic acid moieties, such as Nafion (DuPont) and Aciplex (Asahi Chemicals), possess good chemical and physical properties, as well as high conductivity. ${ }^{1}$ However, they have disadvantageous properties of high methanol permeability, which limits their use in direct methanol fuel cells, and poor performance at temperatures over $100^{\circ} \mathrm{C}$. Recently many research groups have studied how to overcome the drawbacks of Nafion ${ }^{\circledR}$ membranes. ${ }^{2-5}$ Consequently, there have been a number of attempts to modify polymers for proton-exchange membranes, including poly(ether sulfone)s, ${ }^{6,7}$ poly(ether ketone)s, ${ }^{8-10}$ polyimides, ${ }^{11-13}$ polybenzimidazole, ${ }^{14}$ and polyphosphosphazenes. ${ }^{15,16}$ Among these polymers, poly(ether sulfone)s (PESs) have received much attention because of their high thermal, oxidative, and chemical stability in fuel cell environments. ${ }^{17}$

Proton conduction in polymer electrolyte membranes is an intimate function of proton transportation and associated water molecules which are strongly dependent on molecular structure and acidity. It has been reported that polymer structure affects polymer clusters which involves the formation of micelles comprising ion exchange sites and channels. The modification of the chemical structure of polymer membranes, such as variation of polymer backbone or substituents on the phenyl rings, provides for different crystallinity, thermal stability, and proton conductivity. Investigations in this laboratory have been focused on the synthesis of branched polymers with trihydroxy co-monomers as a branching agent and the study of their properties. ${ }^{18,19}$ Branched polymers can be synthesized using any of previous processes by a small amount of polyfunctional branching agent monomer such as triphenols, tetraphenols, dihydric phenols, and hydroxy carboxylic acid. ${ }^{20-22}$ These branched polymers, which differ from most linear thermoplastic polymers, exhibit the characteristics of the non-Newtonian flow over essentially all melt processing conditions.

This work is therefore an attempt to synthesize branched sulfonated membranes with amorphous and crystalline regions using sulfone and ketone groups. These polymers, upon suitable structural modifications, will tend to exhibit a number of desirable properties including dimensional stability, good mechanical strength and reasonably high ionic conductivity. The copolymers were synthesized using bisphenol A, 3,3'disodium-4,4'-difluorophenylsulfone and THPE as a branching agent by condensation polymerization. A series of copolymers were studied by FT-IR, ${ }^{1} \mathrm{H}$ NMR spectroscopy, differential scanning calorimetry (DSC), and thermogravimetric analysis (TGA). In addition, we describe our efforts to investigate the relative properties of branched and linear sulfonated poly(ether sulfone ketone) copolymer membranes. Proton conductivity, water uptake, methanol permeability, and ion exchange capacity (IEC) were evaluated.

\section{EXPERIMENTAL}

\section{Materials}

Bisphenol A, 4,4'-difluorophenylsulfone, 4,4'-difluorobenzophenone, and 1,1,1-tris- $p$-hydroxyphenylethane were pur-

\footnotetext{
${ }^{1}$ Department of Applied Chemistry, Konkuk University, Chungju, Chungbuk, Korea

${ }^{2}$ Department of Materials Sci and Engineering, Chungju National University, Chungju, Chungbuk, Korea

*To whom correspondence should be addressed (Tel: +82-43-840-3579, Fax: +82-43-851-4169, E-mail: wgkim@kku.ac.kr).
} 
chased from Aldrich Chemical Co. and used without further purification. Common reagents such as fuming sulfuric acid (33\%), potassium hydroxide, potassium carbonate, toluene, acetone, and methanol were used without further purification. Dimethylacetamide(DMAC) was dried with $\mathrm{CaH}_{2}$ and used after distillation.

\section{Polymer Synthesis}

Polymerization reaction was conducted in $100 \mathrm{~mL}$ threeneck flasks which were generally equipped with a nitrogen inlet, thermometer, Dean-Stark trap and condenser. A mixture of bisphenol A (7.00 mmol), 3,3'-disodiumsulfonyl-4,4'-difluorophenylsulfone $(2.82 \mathrm{mmol}, 40 \%), 4,4^{\prime}$-difluorobenzophenone (4.23 mmol, 60\%), THPE ( $0.40 \mathrm{~mol} \%$ of bisphenol A), $\mathrm{K}_{2} \mathrm{CO}_{3}$ $(8.40 \mathrm{mmol})$ were added into flask, and dissolved in a mixture of DMAC $25 \mathrm{~mL}$ and toluene $25 \mathrm{~mL}$. The mixture was refluxed for $6 \mathrm{~h}$ at $150^{\circ} \mathrm{C}$, and then excess toluene was distilled off. The mixture was heated at $180^{\circ} \mathrm{C}$ for $24 \mathrm{~h}$. Then the reaction mixture was cooled to room temperature and poured into a mixture of water and methanol to precipitate the copolymer. The crude product was then washed three times with hot water to remove inorganic salts. The purified polymer was filtered and dried in a vacuum at $100{ }^{\circ} \mathrm{C}$ for $24 \mathrm{~h} ; 95 \%$ yield; ${ }^{1} \mathrm{H}$ NMR $\left(\mathrm{DMSO}-d_{6}\right) \quad \delta=1.60-1.75 \quad\left(\mathrm{~s},-\mathrm{C}\left(\mathrm{CH}_{3}\right)_{2}\right), \quad 2.50-2.60 \quad(\mathrm{~s}$, DMSO), 3.40 (s, $\mathrm{H}_{2} \mathrm{O}$ ), 6.65-6.70 (d, THPE), 6.80-7.40 (m, ArH), 7.70-7.80 (broad, sulfone ArH, inside), 7.85-7.95 (s, sulfonyl $\mathrm{ArH}$, inside), 8.20-8.25 (s, $-\mathrm{SO}_{3} \mathrm{Na}$ near $\mathrm{ArH}$ ).

\section{Membrane Preparation}

Membranes in the sodium sulfonate form were prepared first by the redissolution of the polymer in DMSO to afford 5-10\% transparent solutions and then by the casting of the solutions onto clean glass substrates. The films were carefully dried with infrared heat at gradually increasing temperatures (up to $60^{\circ} \mathrm{C}$ ) under a nitrogen atmosphere and then were vacuum-dried at temperatures of up to $150{ }^{\circ} \mathrm{C}$ for $2 \mathrm{~d}$.

\section{Membrane Characterization}

Fourier transform infrared (FT-IR) spectroscopy was used to confirm the pendant functional groups on the polymers. Measurements were recorded using a MIDAS FT-IR spectrometer with thin, homogeneous cast films. The ${ }^{1} \mathrm{H}$ NMR spectra were recorded on a Brucker DRX (300 MHz) spectrometer. DMSO- $d_{6}$ was used as the solvent and tetramethylsilane (TMS) was used as the internal standard. Molecular weights of polymers were determined relative to polystyrene standards by gel permeation chromatography (GPC) in $\mathrm{CHCl}_{3}$ as the eluent on a Perkin Elmer series 200 high-pressure-liquid chromatographer equipped with a set of four styragel columns (500, $10^{4}, 10^{5}$, and $100 \AA$ ) in series and a UV detector. Differential scanning calorimetry (DSC) and thermogravimetric analyses (TGA) were performed with Perkin-Elmer TGA7 and DSC7 at a heating rate of $20^{\circ} \mathrm{C} / \mathrm{min}$ under a gas flow rate of $50 \mathrm{~mL} / \mathrm{min}$.

The membranes were vacuum-dried at $100^{\circ} \mathrm{C}$ for $24 \mathrm{~h}$, weighed and immersed in deionized water at room temperature for $24 \mathrm{~h}$. The wet membranes were wiped dry and quickly weighed again. The water uptakes of membranes are reported in weight percent as follows: water uptake $=\left\{\left(\mathrm{W}_{\text {wet }}-\right.\right.$ $\left.\left.\mathrm{W}_{\text {dry }}\right) / \mathrm{W}_{\text {dry }}\right\} \times 100 \%$ where $\mathrm{W}_{\text {wet }}$ and $\mathrm{W}_{\text {dry }}$ are the weights of the wet and dry membranes, respectively. The titration technique was used to determine the IEC of the membranes. First, the membranes in the acid form $\left(\mathrm{H}^{+}\right)$were converted to the sodium form by immersing the membranes in a $1 \mathrm{M} \mathrm{NaCl}$ solution for $24 \mathrm{~h}$ to exchange the $\mathrm{H}^{+}$ions with $\mathrm{Na}^{+}$ions. Then, the exchanged $\mathrm{H}^{+}$ions within the solutions were titrated with a $0.01 \mathrm{~N} \mathrm{NaOH}$ solution. The theoretical IEC calculated from sulfonated degree was obtained from the formula: IEC (meq./g) = Ionic mmol concentration/Mass of dry membrane at $25^{\circ} \mathrm{C}$. Proton conductivity of membranes was determined from the membrane resistance measured by electrochemical impedance spectroscopy (EIS). The EIS measurements were carried out using a Solartron (Houston, TX) 1250 frequency response analyzer together with the Solartron 1287 electrochemical interface. The membrane resistance was measured in fuel cell hardware with humidified hydrogen applied to both the anode and cathode. The data was recorded using ZPLOT impedance software (Scribner Associates, Inc., Southern Pines, NC) which also controlled the experiments. EIS was conducted at the open circuit condition by applying a small alternating voltage $(10 \mathrm{mV})$ and varying the frequency of the alternating voltage from $1 \times 10^{5}$ to $1 \mathrm{~Hz}$. Methanol diffusion coefficients were determined using the test cell. A solution containing $1 \mathrm{M}$ methanol in water was placed on one side of the diffusion cell, and water was placed on the other side. Magnetic stirrers were used on each compartment to ensure uniformity. Methanol concentrations within the water cell were monitored at different temperatures using a Hewlett Packard ${ }^{\circledR}$ GC chromatograph.

\section{RESULTS AND DISCUSSION}

\section{Polymer Synthesis}

A series of linear and branched sulfonated poly(ether sulfone ketone) (SPESK and Br-SPESK) were prepared as shown in Scheme 1. Br-SPESK was synthesized by reaction of bisphenol A with a 4,4'-difluorobezophenone, 3,3'-disodiumsulfonyl-4,4'-difluorophenylsulfone, and THPE as a branching agent in the presence of potassium carbonate in a DMAC/ toluene solvent system. 3,3'-disodiumsulfonyl-4,4'-difluorophenylsulfone was synthesized by the known procedure. ${ }^{23}$ The polymerization was studied by changing a branching agent in amounts of $0.1-1.0 \mathrm{~mol} \%$ relative to mol of bisphenol $\mathrm{A}$ employed. Polymer containing $0.4 \mathrm{~mol} \%$ of THPE showed suitable properties, but polymer containing over $0.5 \mathrm{~mol} \%$ of THPE was crosslinked itself during the polymerization. ${ }^{19,20}$ The content of disulfonated units is within the range of 10 to $50 \%$ of $4,4^{\prime}$-difluorophenylsulfone. The copolymer using 50 mole $\%$ of sulfonated monomer could not obtain high molecular weight because the polymer was precipitated out during the polymerization, which is influenced solubility. The molecular characteristics of the synthesized polymer were in the range of $M_{\mathrm{n}}$ of $20,000-23,000 \mathrm{~g} / \mathrm{mol}$ and $M_{\mathrm{w}}$ of $54,000-$ 


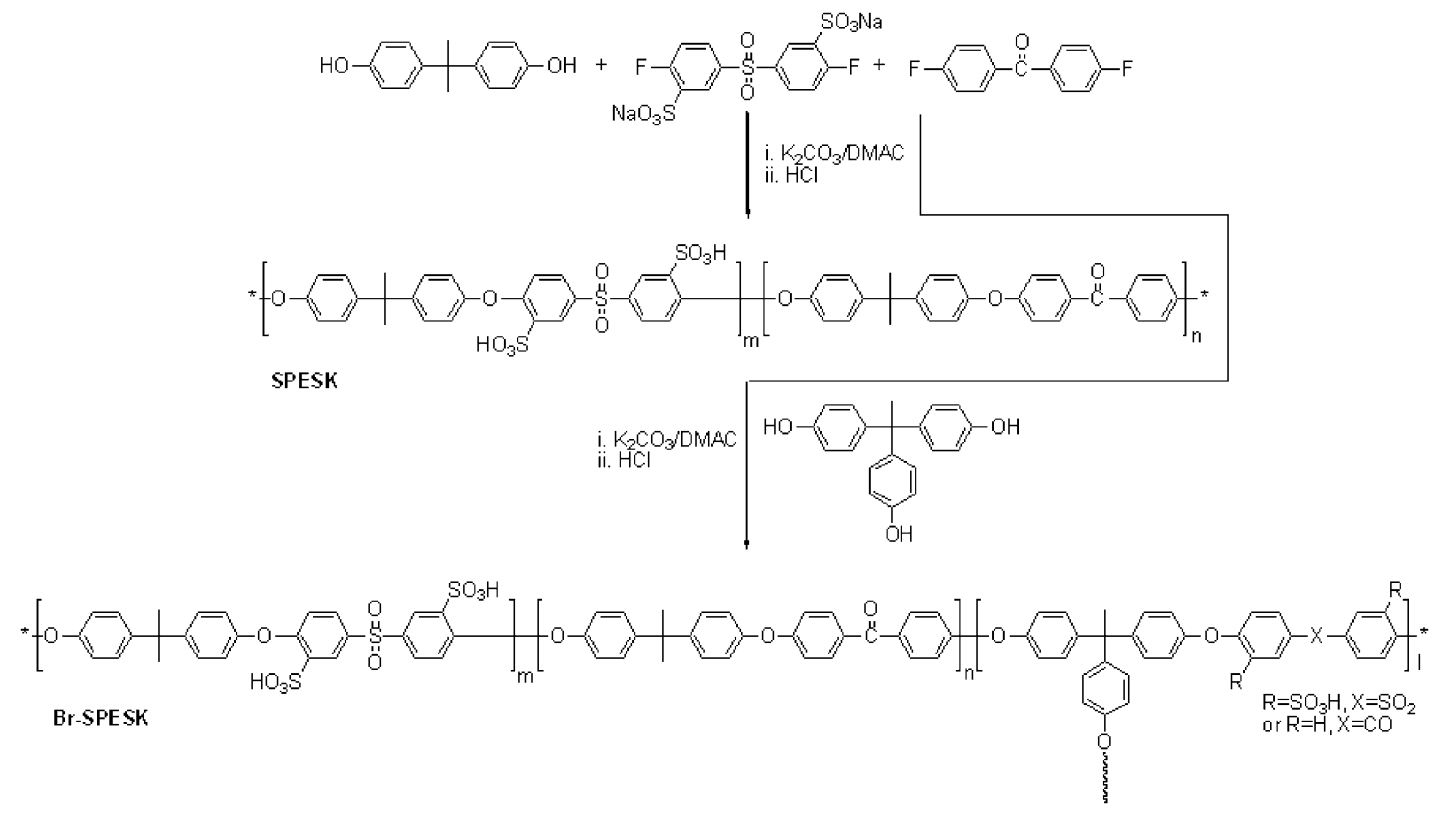

Scheme 1. Scheme of polymerization of branched and linear sulfonated copolymers.
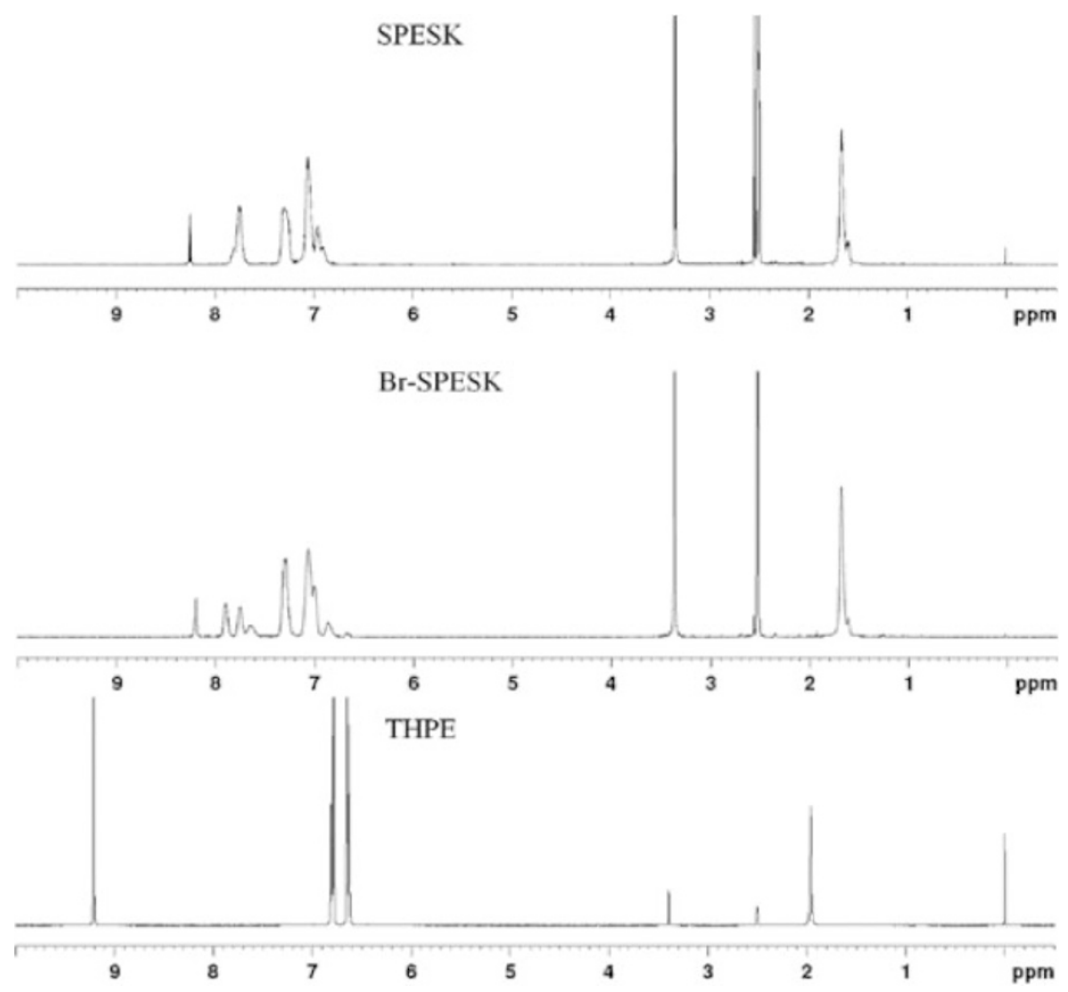

Figure 1. ${ }^{1} \mathrm{H}$ NMR of the Br-SPESK, linear SPESK and THPE.

$62,000 \mathrm{~g} / \mathrm{mol}$. The polydispersities of the copolymers were about 2.69-2.75.

\section{NMR Analysis}

Chemical structures of branched copolymers were identified by ${ }^{1} \mathrm{H}$ NMR shown in Figures 1 and 2 . Figure 1 depicts the ${ }^{1} \mathrm{H}$ NMR spectrum of linear SPESK, Br-SPESK and THPE.
The methyl proton, aromatic proton and hydroxy proton peaks of THPE were observed at 1.90-2.00 ppm, $6.65 \mathrm{ppm}, 6.80 \mathrm{ppm}$ and $9.20 \mathrm{ppm}$ respectively. The linear and branched copolymers were conformed by the appearance of the aromatic protons. ${ }^{1} \mathrm{H}$ NMR conformed that aromatic protons of THPE in Br-SPESK were observed at $6.65-6.70 \mathrm{ppm}$, but the methyl proton peaks of the THPE were not observed at $1.90 \mathrm{ppm}$ 


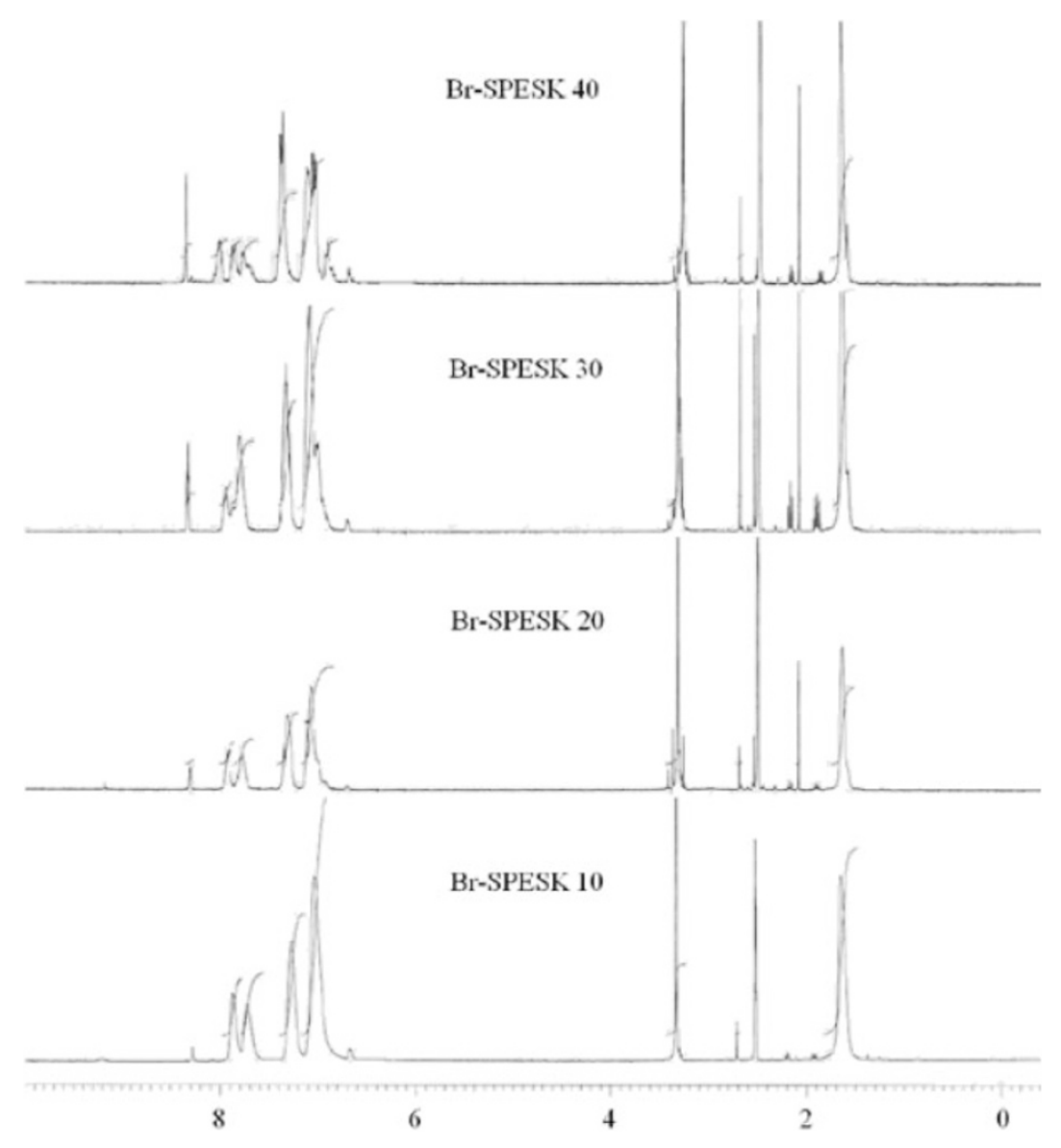

Figure 2. ${ }^{1} \mathrm{H}$ NMR of the Br-SPESK copolymers.

because of the small amount and relatively fewer protons, and no appearance of hydoxy proton peaks of THPE by consumption of reaction. The aromatic protons of THPE in linear SPESK were not observed. The aromatic proton peak next to the sulfone of sulfonated monomer units was observed at 8.20$8.25 \mathrm{ppm}$, and increased as the content of sufonated monomers increased from $10 \%$ to $40 \%$. In Br-SPESK $10 \%$ and $20 \%$, the peaks of hydoxy groups of bisphenol A and THPE were observed at $9.20 \mathrm{ppm}$, which is the trace of terminated hydroxyl groups of polymer chain.

\section{FT-IR Study}

In FT-IR study, the absorption band at 685, 1085, and $1241 \mathrm{~cm}^{-1}$ can be signed to the stretching of the sulfonate group. In terms of increasing the $\mathrm{SO}_{3} \mathrm{H}$ groups, the broad peak at $3500 \mathrm{~cm}^{-1}$ gradually increased which is evidence of a high content of $\mathrm{SO}_{3} \mathrm{H}$ groups in a polymer chain. (Figure 3)

\section{Thermal Study}

The thermal behaviors of linear SPESK, Br-SPESK as a function of $-\mathrm{SO}_{3} \mathrm{H}$ group were investigated by differential scanning calorimetry (DSC), and depicted in Figures 4 and 5. The linear and branched copolymers were amorphous and showed the elevating glass transition as increasing the sulfuric acid group. As increased the $\mathrm{SO}_{3} \mathrm{H}$ group over $40 \%, T_{\mathrm{g}}$ peaks

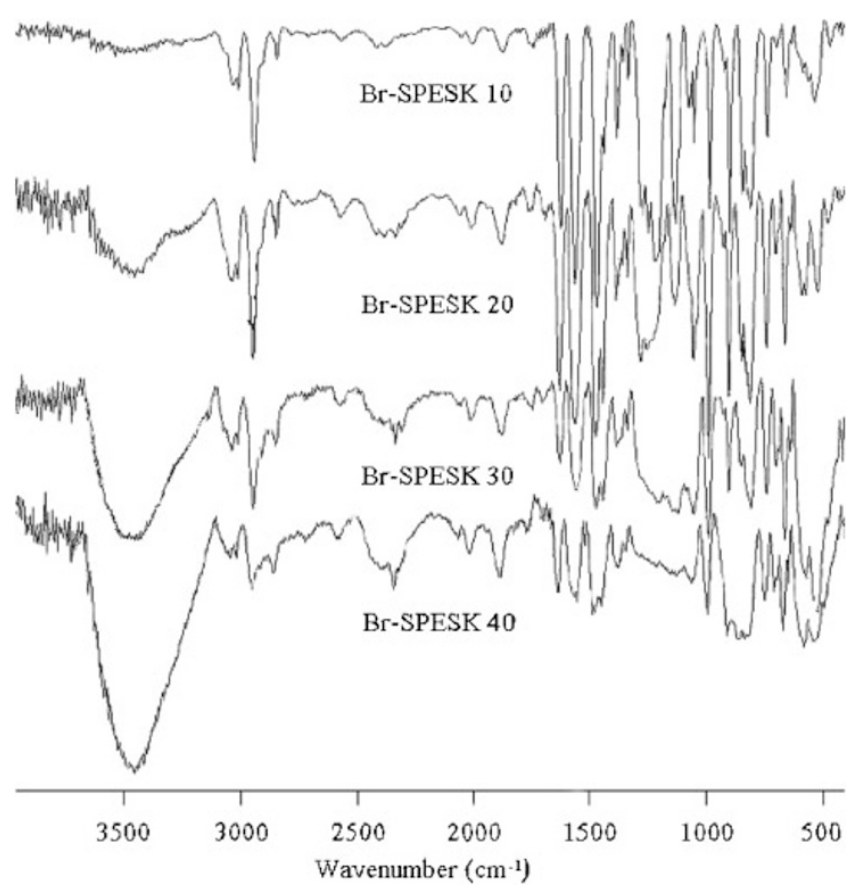

Figure 3. FT-IR of the Br-SPESK copolymers. 


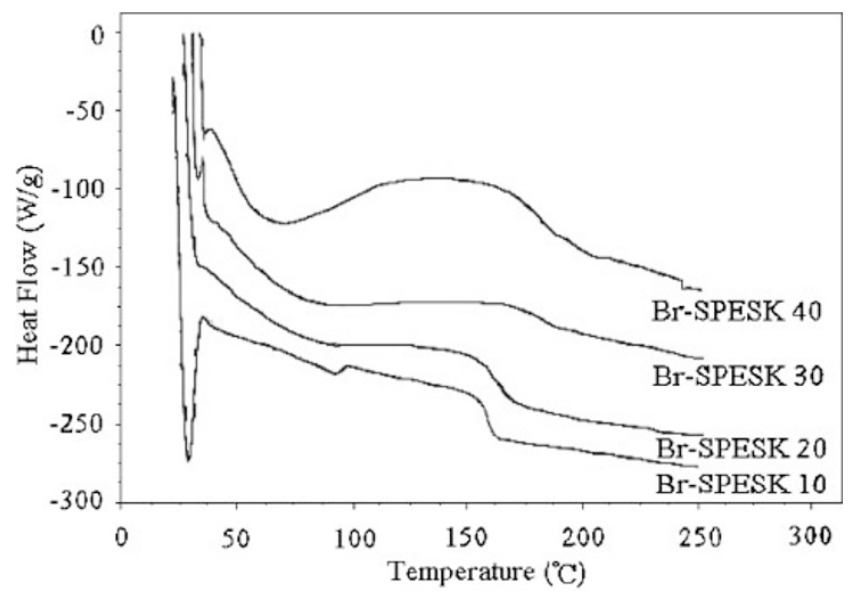

Figure 4. DSC curves of Br-SPESK copolymers.

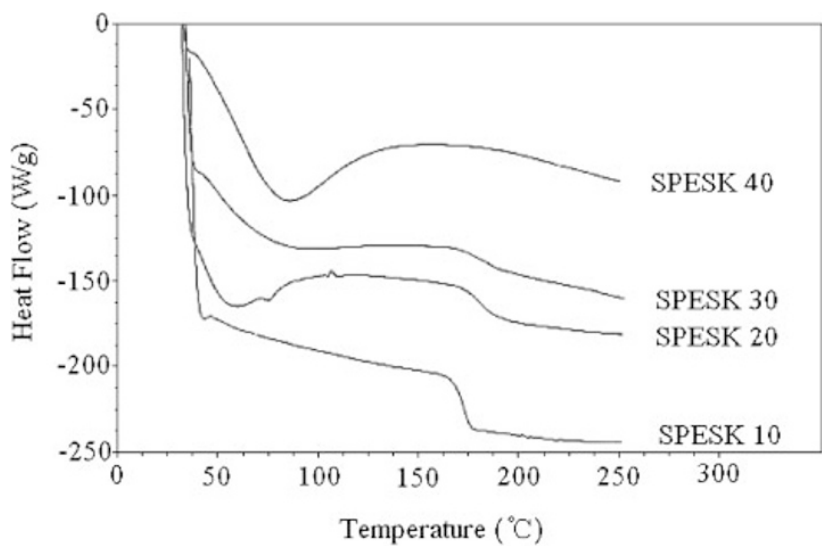

Figure 5. DSC curves of linear SPESK copolymers.

were possibly not shown due to only the high enough rotation energy of $\mathrm{SO}_{3} \mathrm{H}$ groups, but also less segment motion. Thermooxidative stability of Br-SPESK was studied using thermogravimetric analysis (TGA) with results shown in Figure 6. Most of the polymers showed good thermal stability at high temperature in a nitrogen atmosphere. The initial weight loss around $100-200{ }^{\circ} \mathrm{C}$ is attributed to residual solvent (DMAC) and water release from the Br-SPESK. The second weight loss over $250{ }^{\circ} \mathrm{C}$ was assigned to the breakaway of $-\mathrm{SO}_{3} \mathrm{H}$ groups. The mass loss of Br-SPESK 10\% at this temperature was observed lower than those of others because of low content of $-\mathrm{SO}_{3} \mathrm{H}$ groups. The third weight loss over $500^{\circ} \mathrm{C}$ was assigned to degradation of the polymer main chain.

\section{Ion Exchange Capacity and Water Uptake}

The degree of sulfonation (DS) is expressed in the form of the ion exchange capacity (IEC; meq./g). The IECs of the BrSPESK were in the range of $0.35-0.81$ meq. $/ \mathrm{g}$, whereas in the IEC of the Nafion $112^{\circledR}$ appeared $0.91 \mathrm{meq}$./gas shown in Figure 7. In increasing the mole $\%$ of $3,3^{\prime}$-disodiumsulfonyl$4,4^{\prime}$-difluorophenylsulfone monomer, the IEC of Br-SPESK membrane did not reach what was expected because the sulfuric acid groups of monomer were influenced by less

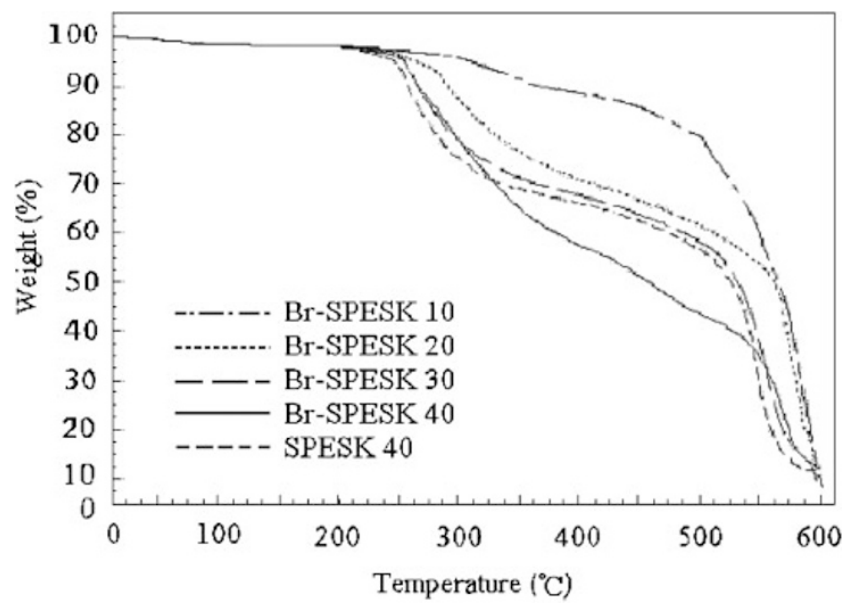

Figure 6. TGA of Br-SPESK copolymers under nitrogen atmospheres.

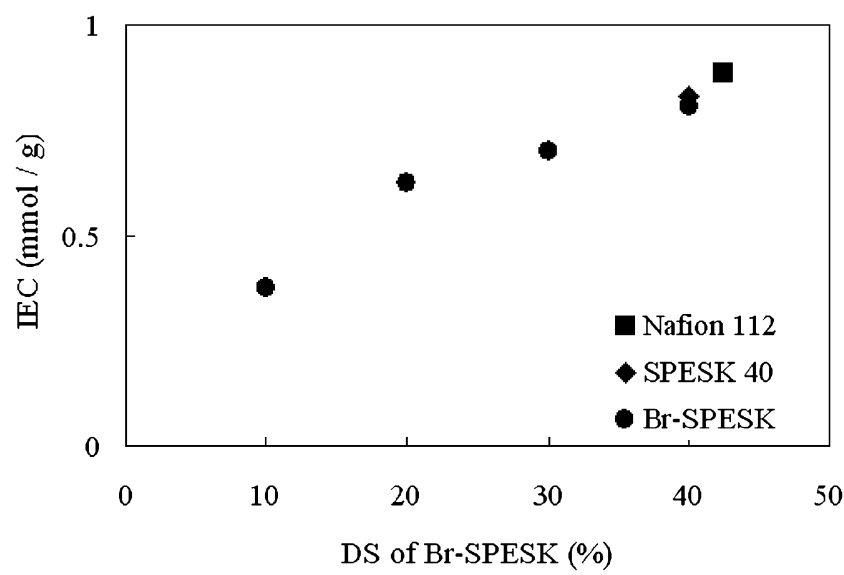

Figure 7. Membrane IEC as a function of DS.

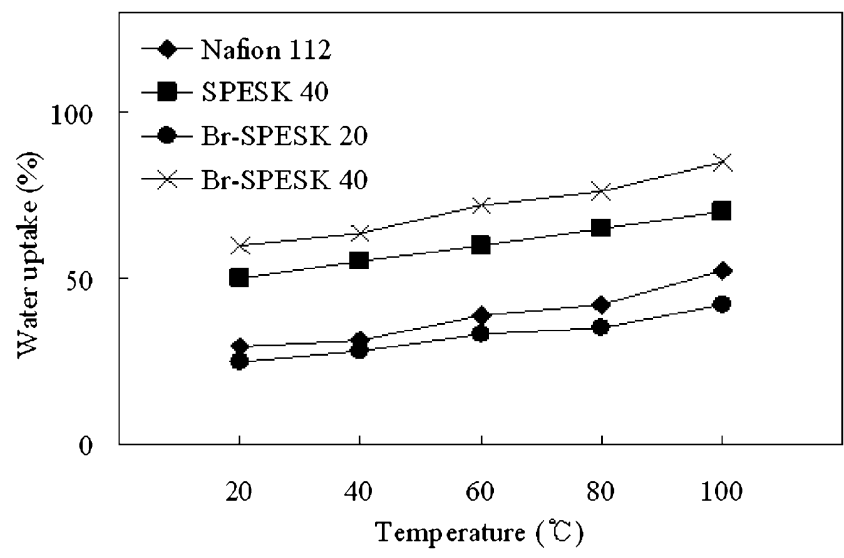

Figure 8. Temperature dependence of water uptake of Br-SPESK, linear SPESK $40 \%$ and Nafion 112.

solubility to produce low molecular weight. Figure 8 shows the water uptake of Br-SPESK as a function of the sulfonation level at room temperature $\left(25^{\circ} \mathrm{C}\right)$. The water uptake of $\mathrm{Br}$ SPESK increased as DS and temperature were increased, whereas Nafion $112^{\circledR}$ showed relatively lower values. The high 
content of DS leads to the membranes being more hydrophilic, and hydrates with water which acts as a plasticizer. Those membranes with high DS have low mechanical strength due to swelling effect which increased with DS and temperature. The differences between Nafion $112^{\circledR}$ and Br-SPESK are due to the microstructure of hydrophobic polymer backbone and hydrophilic sulfuric acid groups. Nafion $112^{\circledR}$, especially, has wide channels which mean good separation of hydrophobic and hydrophilic domains by perfluorinated backbone and sulfuric acid groups. ${ }^{24}$ Therefore, the appropriate DS has to be selected for uses in polymer electrolyte fuel cell membrane. Br-SPESK $\mathbf{4 0 \%}$ was tough and sustained suitable mechanical strength. In comparison to linear SPESK copolymers, Br-SPESK copolymers exhibit slightly improved properties. Branching agents in these branched polymers provided suitable chemical structures to exhibit a number of desirable properties including dimensional stability and good mechanical strength. It has been reported that, at constant molecular weight, the average segment to segment distance is smaller in a branched polymer than in the linear polymer. $^{25}$ As a consequence, the segment density in the polymer coil is increased, the branched polymer is more spherical, and the radius of gyration is decreased.

\section{Methanol Permeability}

Those kinds of behaviors have an influence on polymer properties. Br-SPESK membranes exhibit methanol diffusion coefficients at $25^{\circ} \mathrm{C}$ of $3.10 \times 10^{-7}$ to $4.90 \times 10^{-7} \mathrm{~cm}^{2} / \mathrm{S}$, depending on the degree of sulfonation as shown in Figure 9. These values are around one order of magnitude lower than that of Nafion $112^{\circledR}$ membrane $\left(2.00 \times 10^{-6} \mathrm{~cm}^{2} / \mathrm{S}\right)$ at the same temperatures. Proton conductivities of the series of SPESK, Br-SPESK membranes were measured as a function of the mole fraction of disulfonated units (Figure 9).

\section{Proton Conductivity}

As expected, the conductivity of polymers increases as the degree of sulfonation increases from 10 to $40 \%$. The resulting branched polymer membranes were in the range of $1.02 \times$

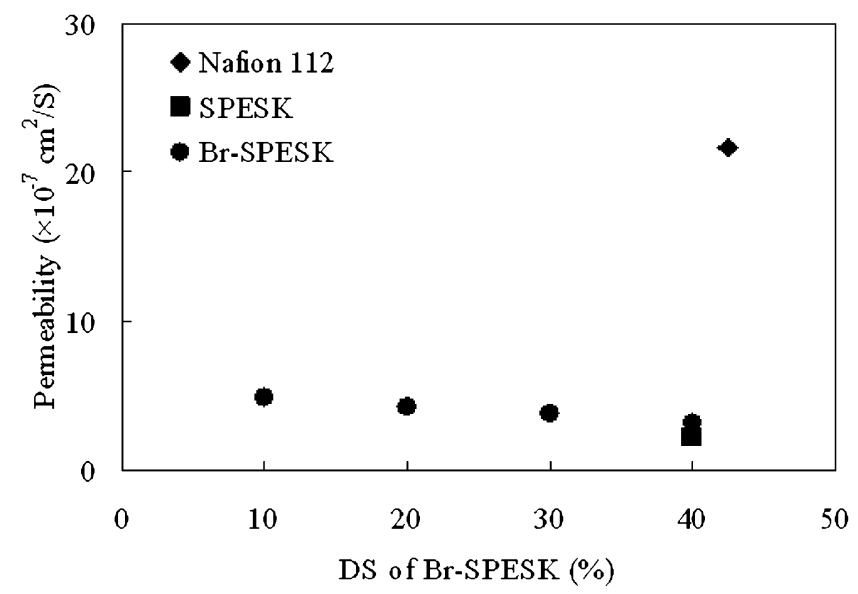

Figure 9. Methanol permeability of Br-SPESK, linear SPESK $40 \%$ and Nafion 112

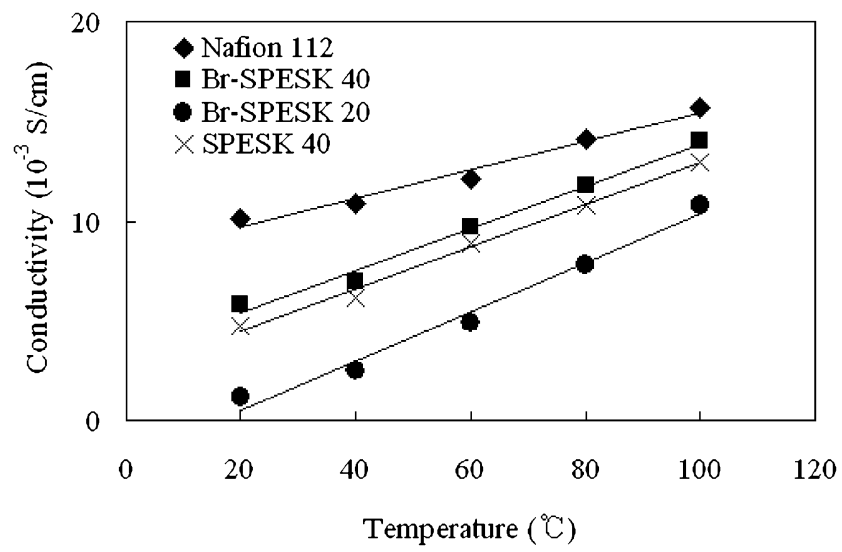

Figure 10. Temperature dependence of the proton conductivity of $\mathrm{Br}$ SPESK, linear SPESK $40 \%$ and Nafion 112.

$10^{-3}$ to $4.53 \times 10^{-3} \mathrm{~S} / \mathrm{cm}$, and increased ion-exchange capacity with an increased degree of sulfonation. The proton conductivity of branched polymer membranes was slightly higher than that of the linear polymer membranes at the same concentration of $\mathrm{SO}_{3} \mathrm{H}$ groups. The conductivity values of the branched polymer membranes are acceptable to use in fuel cell performance even though the values are lower than Nafion $112^{\circledR}$. These comparisons suggest the feasibility of using directly-synthesized Br-SPESK membranes as proton exchange membranes for fuel cell applications. The branched polymer electrolyte membranes using a variety of branching agents will be further researched in the future.

\section{CONCLUSIONS}

A series of high molecular weight, branched with 0.4 mole \% THPE, copolymers containing 10-40 mole \% disulfonation were synthesized and characterized by a variety of methodologies. Compared with Nafion $112^{\circledR}$ membrane, these Br-SPESK membranes show comparable IECs from 0.35 to $0.81 \mathrm{meq} / \mathrm{g}$, water uptake from 22.25 to $61.50 \%$, thermal stability and significantly reduced methanol permeability. However, proton conductivity is still lower that that of Nafion $112^{\circledR}$ as typical hydrocarbon membranes show. This research demonstrated the possibility of synthesizing branched polymer membranes with thermal stability and reduced methanol crossover for fuel cell application.

Acknowledgment. This work was supported by the Regional Innovation Center (RIC) Program conducted by the Ministry of knowledge Economy. and This research was financially supported by the Ministry of commerce, Industry and Energy (MOCIE) and Korea Industrial Technology Foundation (KOTEF) through Human Resource Training Project for Regional Innovation.

Received: May 7, 2008

Accepted: July 11, 2008

Published: August 28, 2008 


\section{REFERENCES}

1. O. Savadogo, J. New Mater. Electrochem. Syst., 1, 47 (1998).

2. H. R. Kricheldorf, L. Vakhtangishvili, and D. J. Fritsch, J. Polym. Sci., Part A: Polym. Chem., 40, 2967 (2002).

3. D. Fritsch, L. Vakhtangishvili, and H. R. Kricheldor, J. Macromol. Sci., Pure Appl. Chem., 39, 1335 (2002).

4. K. T. Adjemian, S. J. Lee, S. Srinivasan, J. Benziger, and A. B. Bocarsly, J. Electrochem. Soc., 149, A256 (2002).

5. K. D. Kreuer, Chem. Mater., 8, 610 (1996).

6. P. Genova-Dimitrova, B. Baradie, D. Foscallo, C. Poinsignon, and J. Y. Sanchez, J. Membr. Sci., 185, 59 (2001).

7. F. Lufrano, G. Squadrito, A. Patti, and E. Passalacqua, J. Appl. Polym. Sci., 77, 1250 (2000).

8. C. Bailly, D. J. Williams, F. E. Karasz, and W. J. MacKnight, Polymer, 28, 1009 (1987).

9. S. M. J. Zaidi, S. D. Mikahailenko, G. P. Robertson, M. D. Guiver, and S. Kaliaguine, J. Membr. Sci., 173, 17 (2000).

10. G. Alberti, M. Casciola, L. Massinelli, and B. Bauer, J. Membr. Sci., 185, 73 (2001).

11. N. Cornet, O. Diat, G. Gebel, F. Jousse, D. Marsacp, R. Mercier, and M. Pineri, J. New Mater. Electrochem. Syst., 3, 33 (2000).

12. C. Genies, R. Mercier, B. Sillion, N. Cornet, G. Gebel, and M. Pineri, Polymer, 42, 359 (2001).
13. Y. T. Hong, B. Einsla, Y. Kim, and J. E. McGrath, Polym. Prepr., 43, 666 (2002).

14. D. Jones and J. Roziere, J. Membr. Sci., 185, 41 (2001).

15. H. R. Allcock, M. A. Hofmann, C. M. Ambler, S. N. Lvov, X. Y. Zhou, E. Chalkova, and J. Weston, J. Membr. Sci., 201, 47 (2002).

16. H. Tang and P. N. Pintauro, J. Appl. Polym. Sci., 79, 49 (2001).

17. K. D. Kreuer, J. Membr. Sci., 185, 29 (2001).

18. S. P. Kim, J. S. Lee, S. H. Kim, B. H. Lee, S. H. Kim, and W. G. Kim, J. Korean Ind. Eng. Chem., 5, 268 (1999).

19. S. P. Kim, B. H. Lee, S. H. Kim, and W. G. Kim, Bull. Korea Chem. Soc. Jpn., 19, 1388 (1998).

20. H. R. Kricheldorf and T. Adebahr, Makromol. Chem., 194, 2103 (1993).

21. C. A. Martinez and A. S. Hay, J. Polym. Sci., Part A: Polym. Chem., 35, 2015 (1997).

22. R. K. Hans, L. Vakhtangishvili, and D. Fritsch, J. Polym. Sci., 40, 2967 (2002).

23. M. J. Sumner, W. L. Harrington, R. M. Weyer, Y. S. Kim, J. E. McGrath, J. S. Riffle, A. Brink, and M. H. Brink, J. Membr. Sci., 239, 199 (2004).

24. T. D. Gieke, G. E. Munn, and F. C. Wilson, J. Polym. Sci., Part B: Polym. Phys., 19, 1687 (1687).

25. J. Roovers, L. L. Zhou, P. M. Toporowski, M. van der Zwan, H. Iatrou, and N. Hadjichristidis, Macromolecules, 26, 4324 (1993). 